\title{
Species and structure of forests in Tampakan Highlands, South Cotabato, Philippines
}

\author{
Justino M. Quimio and Nelson L. Quilario \\ Department of Forest and Wildlife Management and Conservation, College of \\ Forestry and Natural Resources, Visayas State University (formerly Leyte State \\ University), Baybay City, Leyte, Philippines 652I-A
}

\begin{abstract}
The study was conducted in a logged-over forest of Tampakan Highlands that has an elevation of about $1,350 \mathrm{~m}$. It was aimed to assess the timber stocking rate and level of floristic diversity of the forests that may be influenced by future mining operation in the area. Data were collected and presented following the Braun-Blanquet methodology.

Results indicate that Tampakan forests are highly productive, with relatively large trees and highly diverse species despite past logging. Forty-nine (49) timber species and timber stocking rate of $69 \mathrm{cu} \mathrm{m} /$ ha were recorded in the forests. A total of 312 plant species had been listed in the 73 plots or in a combined area of 1.93 ha. The forest still contained most species of the original old-growth forest. The pioneer vegetation dominated by Piper aduncum was very low in species richness. This indicated the importance of natural forest in preserving native flora.

It is recommended that a zoning plan be prepared to demarcate areas that need to be reserved as permanent forest and more effective forest protection schemes be devised. Enrichment planting in pioneer areas should also be undertaken, with active participation of the B'laan tribe.
\end{abstract}

Keywords: Braun-Blanquet, floristic inventory, Philippine forest, Tampakan Highlands

Correspondence: J. M. Quimio Address: Department of Forest and Wildlife Management and Conservation, College of Forestry and Natural Resources. Visayas State University. Baybay City, Leyte, Philippines 6521-A Tel. No. (053) 335-2675

DOI: $10.32945 /$ atr2923.2007 


\section{INTRODUCTION}

Change is inherent in the way we manage natural resources. For instance, the Philippines pushed for a highly industrialized forestry sector in the third quarter of the last century; 1976 marked a boom in the timber industry. However, this was short-lived, alive only in merely 3 decades (DENR, 1992). From being a timber exporter, the Philippines became a net wood importer since 1989 (DENR, 2001). The Philippine government has committed itself to the 1992 Rio de Janeiro convention on biodiversity conservation. Conversely, the National Integrated Protected Areas System (NIPAS) Law was passed in 1992 (Anonymous, 1992), putting most of remaining natural-growth forests under strict protection status. Proclaimed watershed forest reserves became the initial components of NIPAS and, later on, several new reserves were also proclaimed as protected areas.

Biodiversity loss and the current ecological degradation in Philippine landscapes are serious concerns. As of 1992, the remaining old-growth forests constitute only about $2.6 \%$ of the country's total land area (DENR, 1992). These forests are now confined in remote mountain ranges, where they escaped human encroachment because of access constraints and inhospitable terrain. So, it seemed proper for NIPAS law to designate most of remnant natural forests as reserved for biodiversity conservation.

By the turn of the century, however, a new paradigm in the valuation of natural resources came to fore. Republic Act 7942, the Mining Act, was passed in 1995 to boost the mineral industry. When known mineral deposits lie beneath the forests, the question of whether concerns on forest conservation shall prevail over the economic promise in mining now faces reconsideration. The challenge now is how to allow mineral extraction without unduly jeopardizing preservation
of biological wealth in forests.

Exploration for copper-gold deposits in Tampakan Highlands in southerm part of Mindanao started in 1991 and mineral extraction is planned to start soon. This paper reports on the floristic structure of Tampakan forest. The data generated would be useful in determining how valuable these forests are in view of the national strategy in conservation. In the absence of such data, there is no means to say whether Tampakan Highlands have unique set of species compared to the dipterocarp type forests of the lowlands. Damage to 
forest may not be avoided in mining operations. Data on floristic composition are vital benchmark reference when deciding on the mixture of species to plant even if a mere imitation of the original forest is planned to be rebuilt offsite the mining area in a way of compensating for the unavoidable damage to forests.

The primary objective was to describe the floristic structure of forests in Tampakan Highlands. The specific objectives were: 1)To determine the current timber stock of the forest stands to serve as benchmark for monitoring changes in the future; 2) To describe the species composition of the logged-over forest stands; and 3) To assess the floral diversity status of the forest in the area.

\section{METHODOLOGY}

\section{The study area}

Tampakan Highlands lies in northeastern part of South Cotabato in Mindanao at $6^{\circ} 15^{\prime}$ latitude and $125^{\circ}$ longitude. Its main part belongs to the political jurisdiction of the municipality of Tampakan, South Cotabato, while some parts, though much smaller belong to Sultan Kudarat, Maguindanao and Davao del Sur. It is bound by Sultan Kudarat in the north and east and by General Santos City and Sarangani province in the west and south, respectively.

Tampakan Highlands covers a range of mountain peaks over long steep slopes that abruptly grade to an elevation of about $1,400 \mathrm{~m}$. Topography is generally mountainous, predominantly steep but with scattered patches of gentle slopes and rolling fields where the tribal B'laans subsist through farming. Villages are linked by rough roads built by past logging and now maintained passable by the mining company. Along roadsides much of the former forests were replaced already by cornfields and abandoned old clearings that were invaded by mixtures of Saccharum-dominated grassland and pioneer regeneration. Because of difficult routes offered by long rugged slopes and poor road conditions in some parts, forests and tribal communities in Tampakan Highlands were practically isolated from encroachment by lowland communities.

The forests still cover wide areas, or roughly $60 \%$ of the mining company's project area. The forests were logged in the 1980s. Sawable-size residuals 
forest may not be avoided in mining operations. Data on floristic composition are vital benchmark reference when deciding on the mixture of species to plant even if a mere imitation of the original forest is planned to be rebuilt offsite the mining area in a way of compensating for the unavoidable damage to forests.

The primary objective was to describe the floristic structure of forests in Tampakan Highlands. The specific objectives were: 1)To determine the current timber stock of the forest stands to serve as benchmark for monitoring changes in the future; 2) To describe the species composition of the logged-over forest stands; and 3) To assess the floral diversity status of the forest in the area.

\section{METHODOLOGY}

\section{The study area}

Tampakan Highlands lies in northeastern part of South Cotabato in Mindanao at $6^{\circ} 15^{\prime}$ latitude and $125^{\circ}$ longitude. Its main part belongs to the political jurisdiction of the municipality of Tampakan, South Cotabato, while some parts, though much smaller belong to Sultan Kudarat, Maguindanao and Davao del Sur. It is bound by Sultan Kudarat in the north and east and by General Santos City and Sarangani province in the west and south, respectively.

Tampakan Highlands covers a range of mountain peaks over long steep slopes that abruptly grade to an elevation of about $1,400 \mathrm{~m}$. Topography is generally mountainous, predominantly steep but with scattered patches of gentle slopes and rolling fields where the tribal B'laans subsist through farming. Villages are linked by rough roads built by past logging and now maintained passable by the mining company. Along roadsides much of the former forests were replaced already by cornfields and abandoned old clearings that were invaded by mixtures of Saccharum-dominated grassland and pioneer regeneration. Because of difficult routes offered by long rugged slopes and poor road conditions in some parts, forests and tribal communities in Tampakan Highlands were practically isolated from encroachment by lowland communities.

The forests still cover wide areas, or roughly $60 \%$ of the mining company's project area. The forests were logged in the 1980s. Sawable-size residuals 
Table 1. Distribution of plots by site and vegetation type

\begin{tabular}{|c|c|c|c|c|}
\hline \multirow{2}{*}{$\begin{array}{l}\text { Vegetation } \\
\text { Type }\end{array}$} & \multicolumn{3}{|c|}{ Sampling Site } & \multirow[t]{2}{*}{ Total } \\
\hline & Tablu & Pulabato & Danlag & \\
\hline Grassland & 5 & 5 & 5 & 15 \\
\hline Pioneer & 6 & 6 & 6 & 18 \\
\hline Forest & 9 & 10 & 9 & 28 \\
\hline Forest $w /$ coffee & 6 & 6 & - & 12 \\
\hline Total & 26 & 27 & 20 & 73 \\
\hline
\end{tabular}

were apparently geared towards regenerating a highly productive secondgrowth forest. Damage to forest was primarily due to clearing by tribal communities in search for more land to till and this activity continuous deeper into the receding forested areas. Lumbering of cut trees in clearings for local house-making was very seldom and tribal population was still relatively sparse. Timbering seemed to be not a line of trade to the B'laan tribe especially that there is no available mode of transport of wood products to the lowland. These may explain why most forested areas have retained the character of a forest that is recuperating from the effects of logging.

The geologic materials are generally volcanic in origin, with the higher slopes composed of Quaternary and undifferentiated volcanics. The soils are generally deep and sandy loam to clayey. The climate belongs to Type IV according to Coronas (1920) classification, or having rainfall that is more or less uniformly distributed throughout the year. The average annual rainfall recorded at lower part of Tampakan is $1,350 \mathrm{~mm}$ based on the climate data of the Municipal Agriculture Office. However, because of much higher elevation. Tampakan Highland should receive more than this. Cool weather, about $18^{\circ} \mathrm{C}$ on the average, prevails throughout the year.

\section{Sampling method}

The sampling procedure used was purposive. Since the aim was to capture as much species as possible within a limited number of plots, vegetation samples that were as varied as possible in terms of physiognomy and species mixture were sought. Three sampling sites were included in the study. These were in barangays of Tablu, Pulabato and Danlag. In the Philippines, barangays are the smaller political units that compose a municipality or a city. In each sampling site, four vegetation types, such as the grassland, pioneer formation. 
Table 2. The cover dominance scale based on Braun-Blanquet (1964)

\begin{tabular}{ll}
\hline Scale & Parameters \\
\hline 5 & $75-100 \%$ plot cover \\
4 & $50-75 \%$ plot cover \\
3 & $25-50 \%$ plot cover \\
$\mathrm{B}$ & $15-25 \%$ plot cover \\
$\mathrm{A}$ & $5-15 \%$ plot cover \\
$\mathrm{M}$ & $<5 \%$ plot cover, over 50 individuals \\
1 & $<5 \%$ plot cover, $6-50$ individuals \\
+ & $<5 \%$ plot cover, $3-5$ individuals \\
$\mathrm{R}$ & $<5 \%$ plot cover, $1-2$ individuals \\
\hline
\end{tabular}

second-growth forest anci forest under-planted with coffee were considered. The distribution of plots is presented in Table 1. A total of 73 plots were sampled, which gave a total combined area of 1.93 hectares. Plots in grassland and pioneer formation were $10 \mathrm{~m} \times 10 \mathrm{~m}$. In forests, they were $20 \mathrm{~m} \times 20 \mathrm{~m}$.

In the plots, all plant species were identified and listed. Specimen of unknown species were identified through the help of an experienced personnel in the Museum of Natural History at the University of the Philippines at Los Banos. After completing the list, the plot cover dominance by each of the species were determined and recorded based on the Braun-Blanquet (1964) scale shown in Table 2 . For plots in grassland and pioneer vegetation, only one listing of species was made. For plots in second-growth forest and secondgrowth forest under-planted with coffee, two listings of species were prepared: one for the tree layer and another for species in the undergrowth. Determination of cover dominance by species was then done on a per layer basis. The tree layer species included all species that are 7 meters and higher regardless of kinds of plants, mostly trees, shrubs and lianas. Plants below 7 meters were listed as undergrowth species, which also included seedlings of timber species of this height. Thus, species in the tree layer do not include only trees but other plant forms that reach 7 meters or higher. Distinction was given among climbers, either as liana or vine. Vines include those that are short-lived with succulent stems as compared to lianas that are long-lived, woody climbers in big trees.

After taking vegetative data, recording of plot data followed. These included plot number, location, vegetation type, overall percent plot canopy cover, canopy height, ground inclination, soil depth, soil texture and percent 
surface cover by rocks. In forests, the diameter at-breast-height (DBH) or stem diameter at about $1.3 \mathrm{~m}$ from the ground, height to first major branch, total height and species name of trees were determined. The measurements included only trees that have DBH of at least $30 \mathrm{~cm}$.

\section{Data analysis}

Analysis of data on species composition was primarily based on the number of species in different vegetation types and comparison of species composition based on the Jaccard similarity indices. The measure of diversity was based only on the number of species. The discussion of results in this article did not attempt to compare data with the results in other studies since reports that use the same methods in this study were still very limited. At this point, reporting of the species composition of forests in different localities even without complicated analysis shall be enough, until such time that enough data would be available in literature for combined analysis across sites and vegetation types.

\section{RESULTS AND DISCUSSION}

\section{Timber component}

In the tree layer, 49 species of trees having DBH of $30 \mathrm{~cm}$ and bigger were found in the study (Table 3). Timber species with moderate to high frequency included Syzygium brevistylum, Palaquium luzoniense, Dysoxylum gaudichaudianum, Cinnamomum mindanaense, Lithocarpus llanosii, Elaeocarpus gigantifolius, Podocarpus imbricatus, Ficus balete, Bischofia javanica, Trema orientalis, Cryptocarya glauciphylla, Dillenia philippinensis and Aphanamixis perrottiana. The high number of commercially important timber species indicate that most forest species in the area were preserved even after logging. Except for one plot that was taken in Sitio Pulabato where the elevation is about $800 \mathrm{~m}$, no dipterocarp species were found. In high elevations of Tablu and Danlag of over $1,000 \mathrm{~m}$. dipterocarps from seedlings to mature size were not observed. One distinctive 
Species and structure of forests in Tampakan Highlands

Table 3. Species frequency by diameter (DBH) class

\begin{tabular}{|c|c|c|c|c|c|c|c|}
\hline Species & $30-50$ & $50-70$ & $70-90$ & $90-110$ & $110-130$ & $>130$ & $\mathrm{n}$ \\
\hline Syzygium brevistylum & 39 & 15 & 7 & 7 & 6 & 1 & 75 \\
\hline Podocarpus imbricatus & & 4 & 1 & -9 & & 6 & 20 \\
\hline Ficus balete & 1 & & & 6 & 2 & 4 & 13 \\
\hline Persea philippinense & 2 & 3 & & & 1 & & 6 \\
\hline Palaquium luzoniense & 30 & 17 & 6 & 6 & & & 59 \\
\hline Dysoxylum gandichandianum & 35 & 7 & 3 & 4 & & & 49 \\
\hline Lithocarpus llanosii & 10 & 5 & 5 & 5 & & & 25 \\
\hline Elaecarpus gigantifolius & 10 & 10 & 2 & 2 & & & 24 \\
\hline Litsea garciae & 1 & 2 & 1 & & & & 4 \\
\hline Cinnamomum mercadoi & 34 & 7 & 1 & & & & 42 \\
\hline Crytocarya glauciphylla & 5 & 1 & 7 & & & & 13 \\
\hline Myrica javanica & 3 & & 1 & & & & 4 \\
\hline Syzygium calubcob & 3 & 1 & 1 & & & & 5 \\
\hline Fragraea obovata & 2 & & 1 & & & & 3 \\
\hline Symplocos polyandra & 1 & 1 & 1 & & & & 3 \\
\hline Clausena anisumolens & & & 1 & & & & 1 \\
\hline Trema orientalis & 9 & 1 & & & & & 10 \\
\hline Aphanamixis perrottiana & 5 & 3 & & & & & 8 \\
\hline Eurya japonica & 2 & 3 & & & & & 5 \\
\hline Matthea philippinense & 4 & 1 & & & & & 5 \\
\hline Calophyllum blancoi & 1 & 3 & & & & & 4 \\
\hline Matthea sancta & 1 & 3 & & & & & 4 \\
\hline Toona calantas & 3 & 1 & & & & & 4 \\
\hline Memecyclon blanceolatum & 2 & 1 & & & & & 3 \\
\hline Terminalia citrina & 2 & 1 & & & & & 3 \\
\hline Heliciopsis artocarpoides & $s 1$ & 1 & & & & & 2 \\
\hline Pahudia rhomboides & 1 & 1 & & & & & 2 \\
\hline Medinella myrtiformis & & 1 & & & & & 1 \\
\hline Walsura aherniana & & 1 & . & & & & 1 \\
\hline Dillenia philippinense & 9 & & & & & & 9 \\
\hline Pometia pinnata & 8 & & & & & & 8 \\
\hline Garuga floribunda & 4 & & & & & & 4 \\
\hline Astronia rolfei & 3 & & & & & & 3 \\
\hline Vaccinium philippinense & 3 & & & & & & 3 \\
\hline Antiaris toxicaria & 2 & & & & & & 2 \\
\hline Ficus ulmifolia & 2 & & & & & & 2 \\
\hline Lithocarpus buddii & 2 & & & & & & 2 \\
\hline Mallotus confusus & 2 & & & & & & 2 \\
\hline Total & 257 & 101 & 41 & 39 & 9 & 1 & 458 \\
\hline
\end{tabular}

Species represented by single tree in $30-50 \mathrm{~cm}$ DBH class. Beilschemieda nervosa, Elaeocarpus multiflorus, Hopea acuminate, Paralstonia clusiaca, pouteria veluntina, raermachera pinnata, Sauraria erythrotricha and Spondias romblonensis.

Total species $=49$ 
feature of the forest was the high frequency of igem, Podocarpus indicus, a timber species that was not observed naturally growing at lower elevations of Tampakan Highlands. High frequency of ulaian (Lithocarpus llanosii) in the area is consistent with common observation of its increased predominance in most logged-over forests, which was also reported in logged-over lowland dipterocarp forests of Samar (Quimio and Patindol, 1999). The occurrence of anabiong (Trema orientalis), a light-demanding pioneer tree species, indicated the occurrence of relatively large canopy opening in some parts of the forest.

The predominance of trees in the $30-70 \mathrm{~cm}$ DBH range or the much fewer trees above $70 \mathrm{~cm}$ DBH could be expected in logged-over forests such as those in Tampakan Highlands. Timber license agreements in the Philippines stipulate selective logging, such as only logs with DBH of $60 \mathrm{~cm}$ and above can be harvested. Estimate on tree stem density was 293 trees per hectare. The timber stocking rates in secondary forests based on samples taken in Pulabato, Danlag and Tablu were 85.9,63.2 and $58.8 \mathrm{cu} \mathrm{m} / \mathrm{ha}$. Considering that bigger trees had been removed already by past logging, such stocking rate indicated that forests in Tampakan Highlands are highly productive. The canopy height in plots of forests and in forest under-planted with coffee ranged from $22 \mathrm{~m}$ to $55 \mathrm{~m}$. These indicated that most trees are residual trees and not from seedlings that grew after logging. The logged-over forests show positive signs that they are recuperating towards restoration of its original character.

\section{Diversity in species}

A total of 312 plant species were recorded in the study area (Table 4). Of these 17 species were grass, 49 herb, 18 fern, 13 vine, 15 liana, 13 shrub and 187 tree. As expected, the non-tree species predominated in number in grassland and pioneer formation. Tablu, Pulabato and Danlag had recorded 125,131 and 129 tree species in logged-over forests, respectively, which may indicate comparable level in diversity in tree species among the 3 sites. A lower number of species were recorded in plots where the forest has been under-planted with coffee compared to forest stands that did not have this
kind of human disturbance. 
4. Number of species of different life forms to compare diversity among vegetation types and study sites. Tampakan Highlands. 2005.

\begin{tabular}{|c|c|c|c|c|c|c|c|c|}
\hline \multirow{2}{*}{$\begin{array}{l}\text { Vegetation types } \\
\text { Tablu }\end{array}$} & \multicolumn{7}{|c|}{ LIFE FORM } & \multirow[t]{2}{*}{ TOTAL } \\
\hline & Grass & Fern & Herb & Vine & Liana & Shrub & Tree & \\
\hline Grassland & 13 & 6 & 21 & 4 & 1 & 6 & 10 & 61 \\
\hline Pioneer & 6 & 3 & 7 & 4 & 1 & 2 & 22 & 45 \\
\hline Secondary Forest & 1 & 13 & 12 & 5 & 12 & 5 & 125 & 173 \\
\hline Fores/ with coffee & $\dot{-}$ & 10 & 12 & 4 & 10 & 1 & 92 & 129 \\
\hline Sub-total & 13 & 13 & 21 & 5 & 12 & 6 & 125 & $\cdot$ \\
\hline \multicolumn{9}{|l|}{ Pulabato } \\
\hline Grassland & 6 & 1 & 9 & 4 & 1 & 5 & 1 & 27 \\
\hline Pioneer & 9 & 8 & 17 & 3 & 3 & 22 & 7 & 69 \\
\hline Secondary Forest & 4 & 15 & 16 & 7 & 14 & 5 & 131 & 192 \\
\hline Forest/with coffee & - & 10 & 14 & 6 & 10 & 2 & 100 & 142 \\
\hline Sub-total & 9 & 15 & 17 & 7 & 14 & 22 & 131 & - \\
\hline \multicolumn{9}{|l|}{ Danlag } \\
\hline Grassland & 6 & 4 & 12 & 2 & 1 & 3 & 11 & 39 \\
\hline Pioneer & 8 & 2 & 8 & 3 & 1 & 7 & 21 & 50 \\
\hline Secondary Forest & - & 12 & 12 & 5 & 13 & 4 & 129 & 175 \\
\hline Sub-total & 8 & 12 & 12 & 5 & 13 & 7 & 129 & - \\
\hline Total, 3 sites & 17 & 18 & 49 & 13 & 15 & 13 & 187 & 312 \\
\hline
\end{tabular}

The degree of similarity in species composition among vegetation types based on Jaccard index is presented in Table 5 . About $43 \%(\mathrm{Js}=0.43)$ of the species in grassland and pioneer vegetation occurred in both vegetation types. Between grassland and second-growth forest, the species common to both was only $7 \%$ of their combined number of species. Between grassland and second-growth forest under-planted with coffee, the species common to both was only $4 \%$. This low similarity in species composition between grassland and second-growth forest under-planted with coffee suggested low level of intrusion by grassland species into the second-growth forest even after underplanting with coffee. This could be due to shading effects by the big trees. Between second-growth forest and second-growth forest with coffee, high degree of similarity in species composition $(\mathrm{Js}=0.59$ ) was recorded. Underplanting of coffee did not show drastic change in floristic diversity in secondgrowth forest. This can be because of maintenance of the canopy of big timber trees as discussed earlier.

Between pioneer vegetation and second-growth forest, $\mathrm{J}_{\mathrm{S}}=0.13$, which indicates marked difference in species composition. This illustrates the 
Table 5. The Jaccard indices indicating the degree of similarity in species composition amo. vegetation types. Tampakan Highlands. 2005.

\begin{tabular}{lcccc}
\hline Vegetation Types & Grassland & Pioneer & Secondary Forest & Total Species \\
\hline Grassland & - & & & 76 \\
Pioneer & 0.43 & - & - & 99 \\
Secondary Forest & 0.07 & 0.13 & 0.59 & 213 \\
Forest with coffec & 0.04 & 0.06 & & Total \\
& & & & 312 \\
\hline
\end{tabular}

disappearance of most forest species when natural forests are replaced by pioneer vegetation and grassland via clearing for crop production. Removal of big trees results to opening up of the canopy, which soon triggers invasion by open land species that are associated to grassland and pioneer formations. Open grassland and pioneer tree formation were prevented from regenerating back into closed canopy forests as farmers intermittently return to these sites to farm again.

Association of species to certain vegetation types was analyzed based on the level of confinement in occurrence to any particular vegetation types in reference to the vegetation table (Appendix Table 1). The table show that species associated to grassland and pioneer vegetation (Plot 1-33) were most of the time absent in forests (Plot 34-73). Conversely, except for few pioneer species that invaded canopy gaps in forest, forest species were confined to plots in forests. This also explains the low similarity index in species composition of grassland and pioneer formation when compared to forests. Some species in second-growth forests were not recorded as occurring in forests that are under-planted with coffee. This was due to management intervention in coffee plantation such that undergrowth species are removed by weeding and brushing. This should remind us that human intervention, intentional or unintentional, can always affect negatively the natural process in conserving floral diversity.

In pioneer formation, the most commonly dominating species was spike pepper, Piper aduncum (Plot 16-33). The aggressiveness in growth in open land by spike pepper is an advantage as it provides effective vegetative cover to soil against erosion. That aggressiveness, however, also results to a vegetative formation that is poor in species as other species could not effectively compete for sunlight. The number of species per plot was 9 to 30 but most of them are grassland species. The trees were mostly pioneer species. No commercial 
tree species associated with natural growth forests were recorded in plots from pioneer formation. The low number of species in pioneer formation that is dominated by spike pepper indicated the need for enrichment planting.

\section{CONCLUSION AND RECOMMENDATION}

The study arrived at the following conclusions and recommendations:

1. The logged-over forests in Tampakan highlands are highly productive, still highly stocked with commercial-size timber and containing high diversity of forest floral species. A zoning plan that will identify areas that have to be left as permanent forest needs to be established. Effective strategies for the protection of areas allocated to conservation should be devised in cooperation with the B'laan tribe.

2. The species composition of the Tampakan forest is unique compared to dipterocarp type forests of areas in lower elevations. Floristic studies in forest in varied elevation ranges in other regions of the country should be pursued to aid selection of areas for conservation. More data on floristic composition from a wide range of site conditions would be necessary to have a more comprehensive analysis on response of forests to different conditions.

3. Pioneer formations particularly those dominated by spike pepper are aggressive in invading open grassland but such vegetative cover is very low in species richness. Areas with this type of vegetative cover should be subjected to enrichment planting to improve floristic diversity. This means under-planting with tree species that are native to the area.

4. Human intervention in the remaining logged-over forests can cause reduction in species diversity, particularly in trees, as was the case in underplanting the remaining big trees with coffee. Weeding practically removes the plants at ground layer and the regenerating tree seedlings. Trimming of branches in big trees to allow sunlight to reach planted coffee below can also affect the shade-dependent species.

5. More baseline data collection on timber stock and species composition over the parts of Tampakan that still have forests should be undertaken. It would be advantageous to generate a map that would show which parts of the forests are still having dense stands of timber and those that are already covered 
by other types of vegetation. This map could then become the benchmark in determining which parts are improving or are declining in terms of quality of vegetative cover, where rate of loss of forest could be disturbing or where program for forest rehabilitation is most needed. On the part of the mining company, to which ecological conservation is viewed by the local people as their moral obligation, the same benchmark would be needed to show their effectiveness in the protection of forest resources in their project site and vicinity.

\section{ACKNOWLEDGMENT}

The financial support and logistics provided by the Sagittarius Mines, Inc. during the conduct of the study are highly appreciated.

\section{LITERATURE CITED}

Anonymous. 1997. The Indigenous Peoples Rights Act. Congress of the Philippines, Manila.

Anonymous. 1995. Republic Act No. 7942: Philippine Mining Act of 1995. Congress of the Philippines. Manila.

Anonymous. 1992. The national integrated protected areas system (NIPAS) act of 1992. Congress of the Philippines. Manila.

BRAUN-BLANQUET, J. 1964. Pflanzensoziologie. 3rd ed. Hamburg. 865p.

CORONAS, J. 1920. Climate and weather of the Philippines 1903-1918. Bureau of Printing. Manila. 195p.

DENR 1992. Philippine forestry statistics. Department of Environment and Natural Resources (DENR). Quezon City.

DENR. 2001. Philippine forestry statistics. Quezon City.

QUIMIO, J. M. and T.A. PATINDOL. 1999. Samar island biodiversity project: preliminary floral inventory. Project Report to DENR, Tacloban City. 80p. 

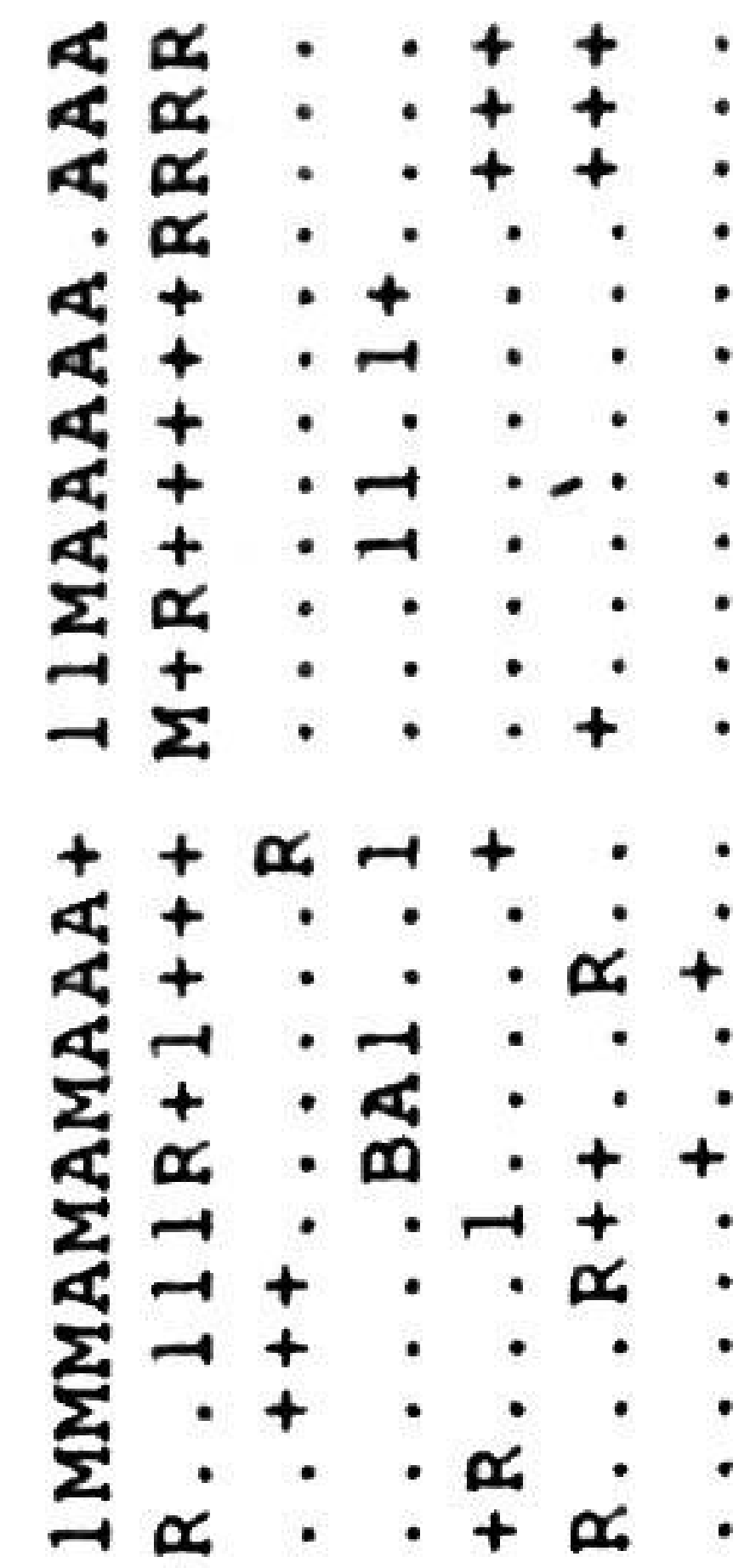

$\rightarrow+$

更+

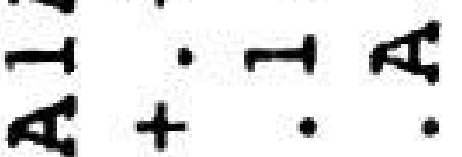

$\underbrace{+}_{\infty}$

$\rightarrow \infty \cdot \ldots$

$+\dot{\alpha} \dot{x}: \infty$

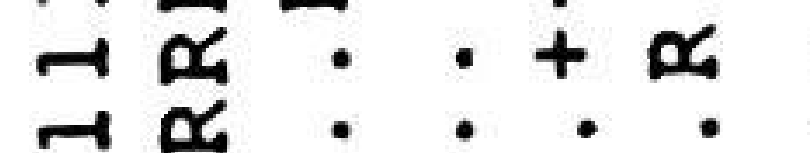

$\rightarrow \underset{\alpha}{\alpha}:$ : :

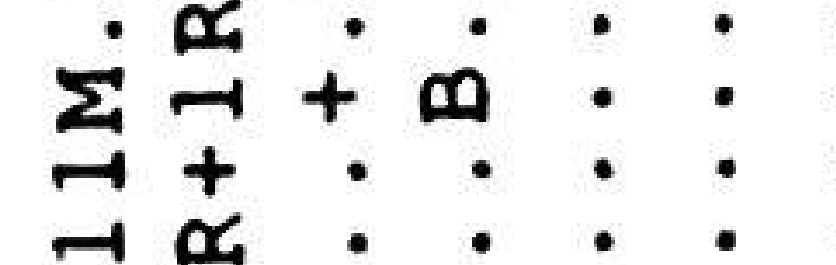

$: \vdots: \propto:: \stackrel{x}{\infty} \quad: m$

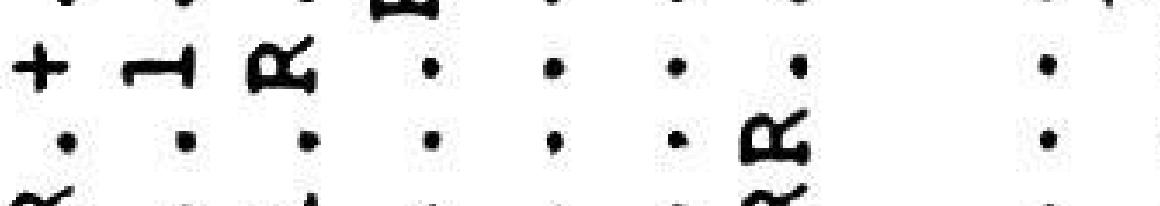

: $\mp:: \dot{\alpha}$

$\dot{\alpha}: \propto:+$

$\alpha: \infty: \cdots$

$++\infty \vdots:+\infty m$

$0^{\infty}::: \dot{\alpha}^{+}$

$+\div::: \vdots \propto$

$++\cdots \cdot a$.

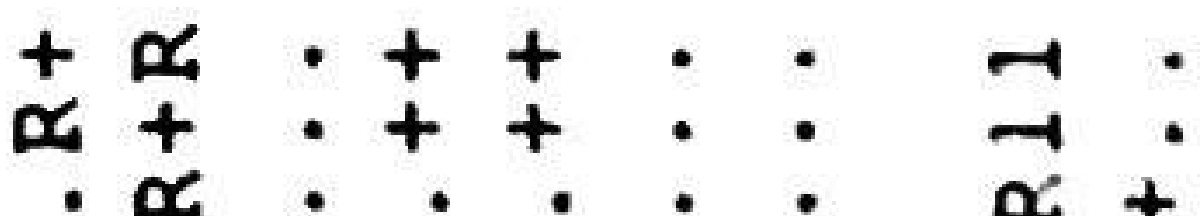

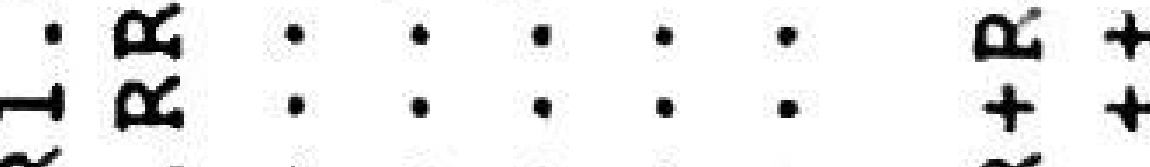

$\alpha$

$\sum_{+}^{+\infty} \underset{\infty}{+\infty}$

:

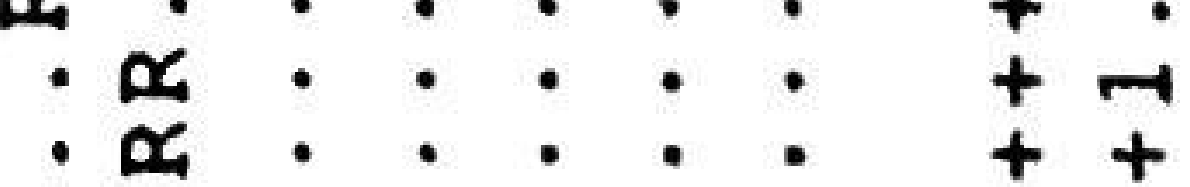

$\propto:::::$ :

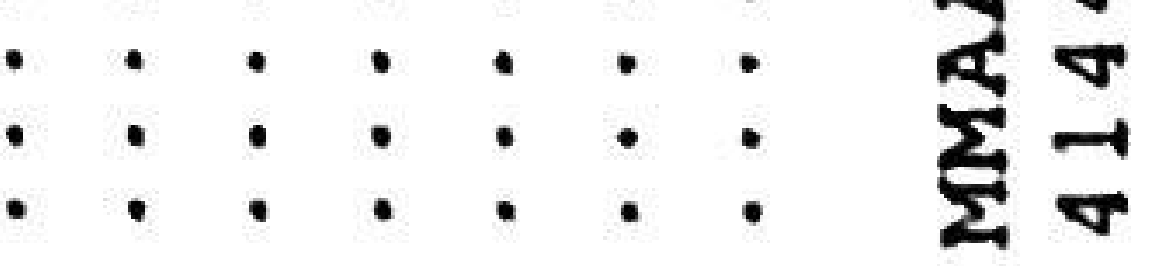

祭

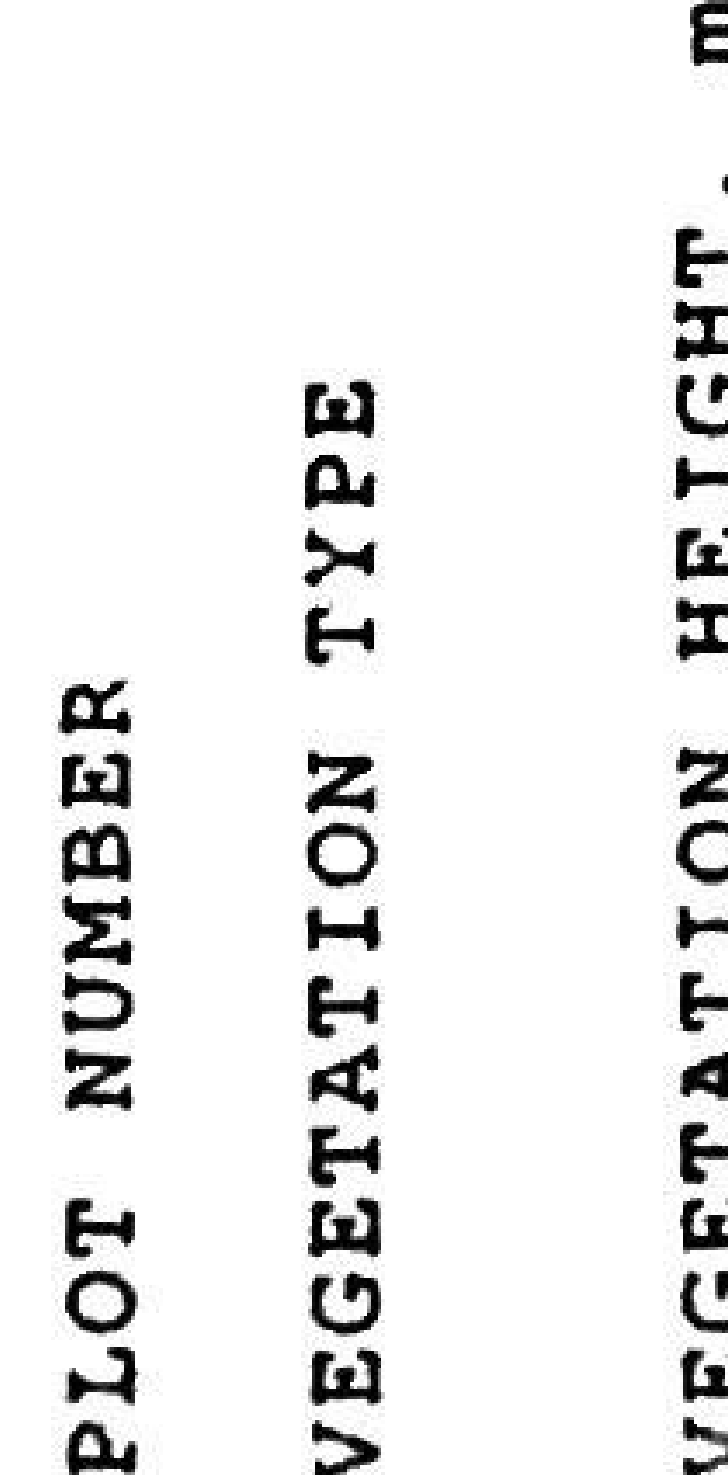

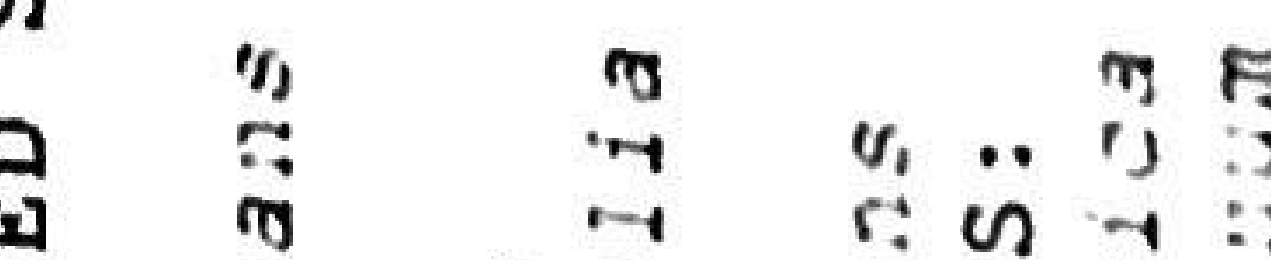

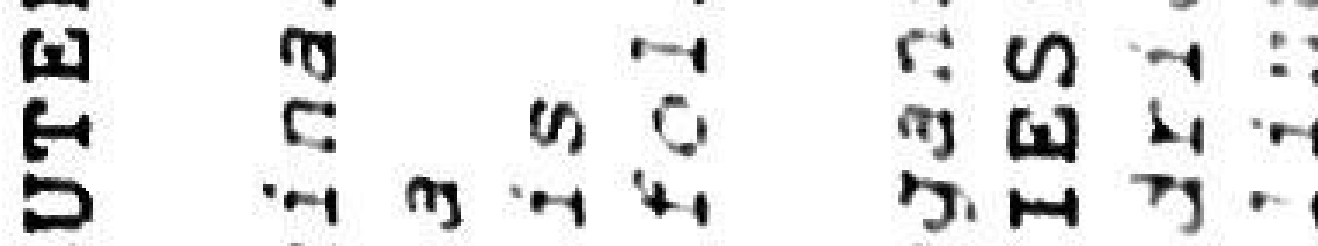
का

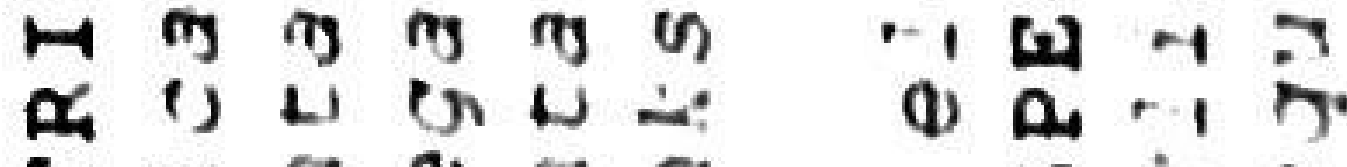

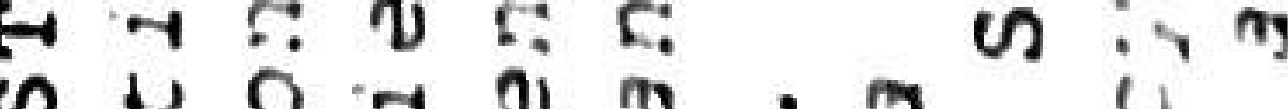

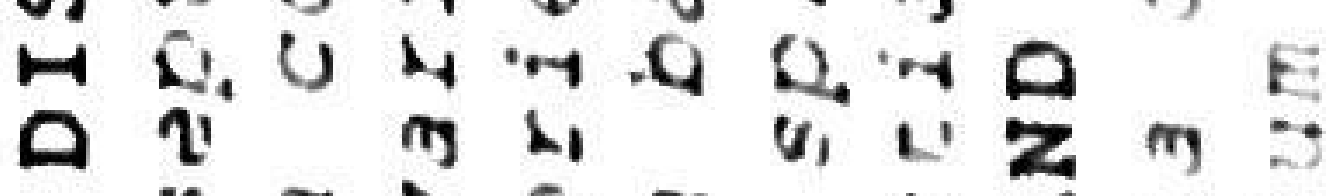

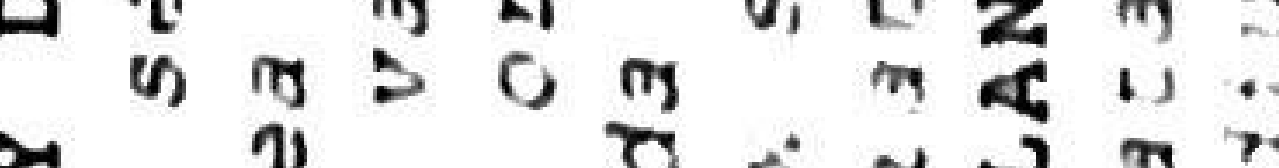
पै v.

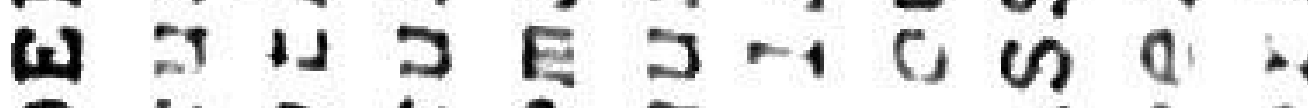

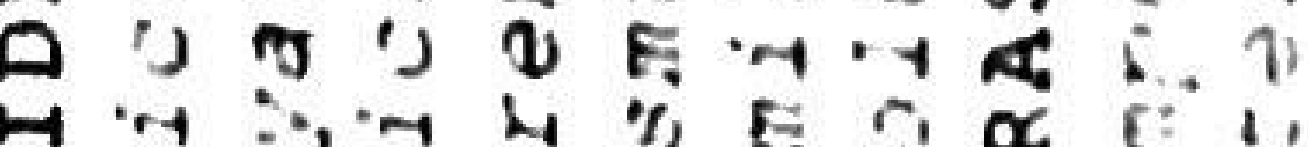




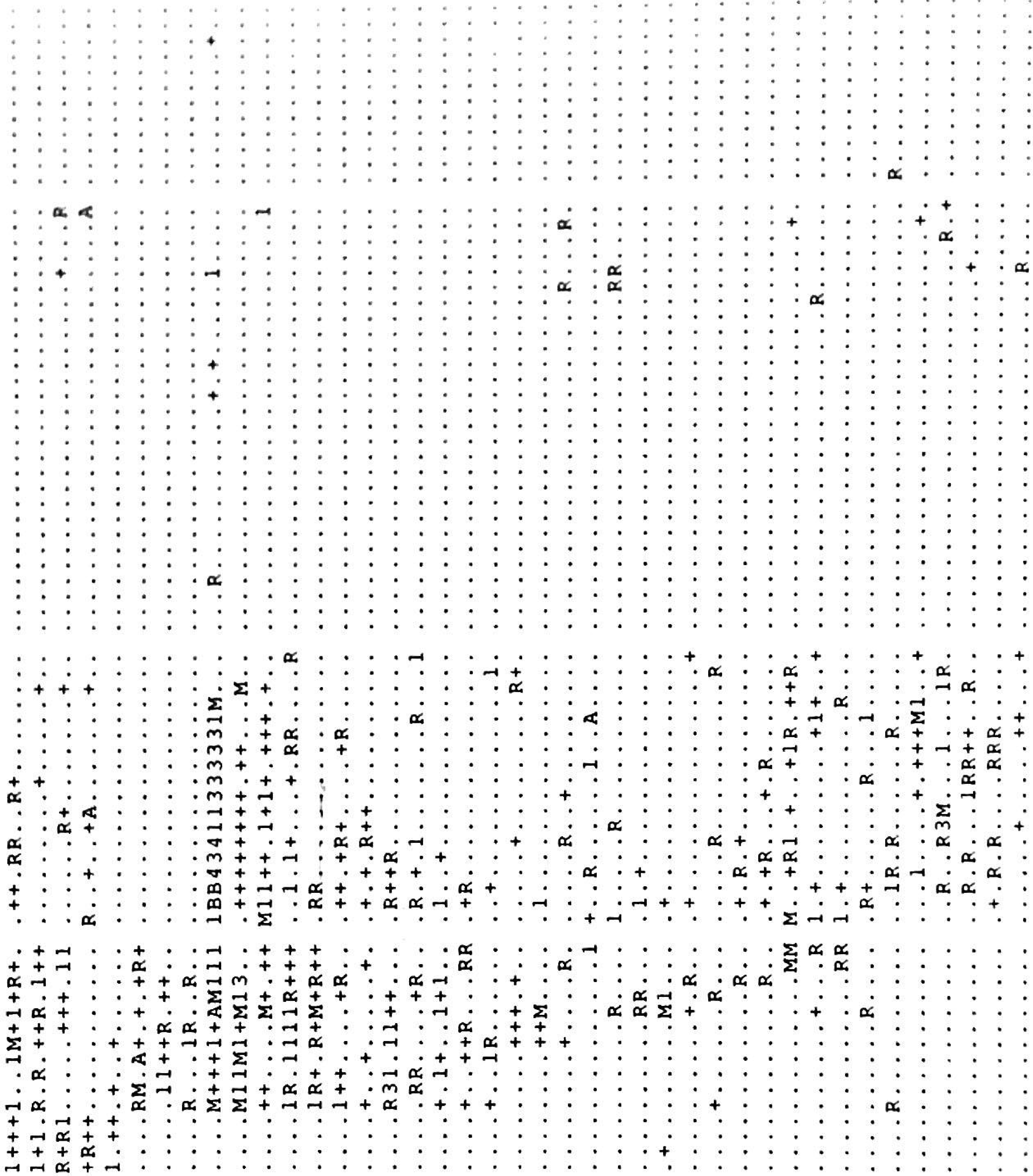

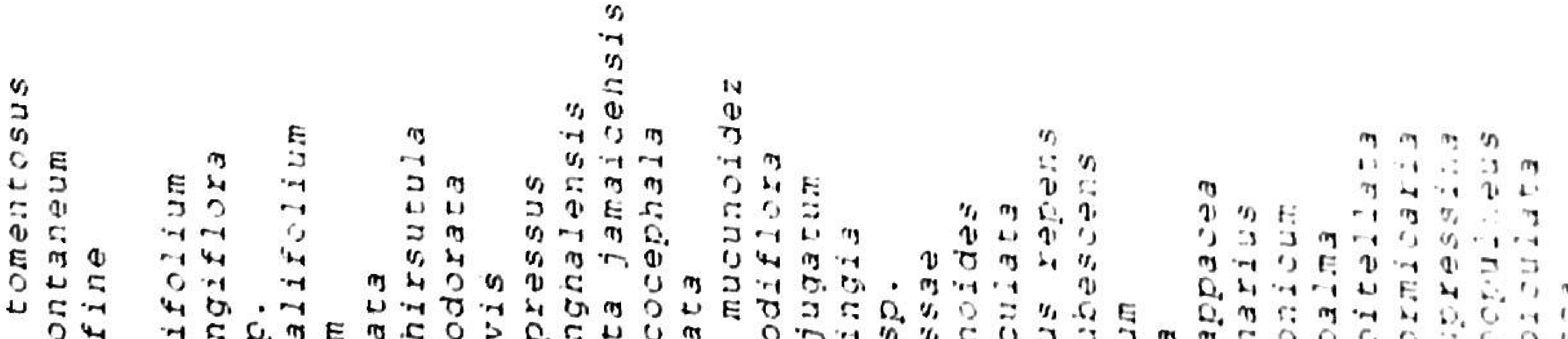
"

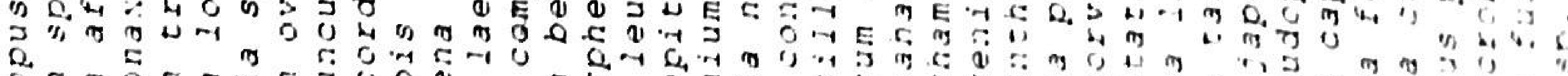

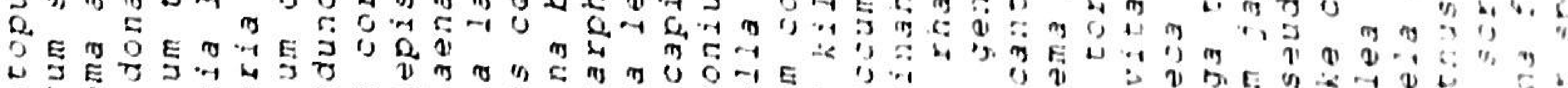

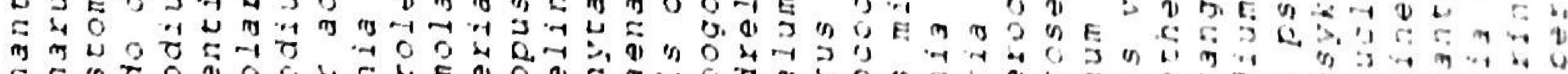

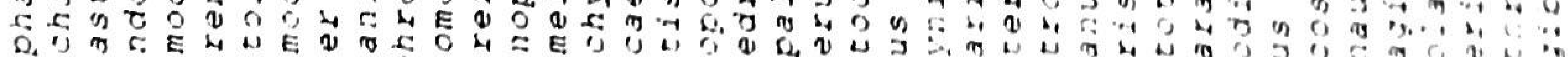

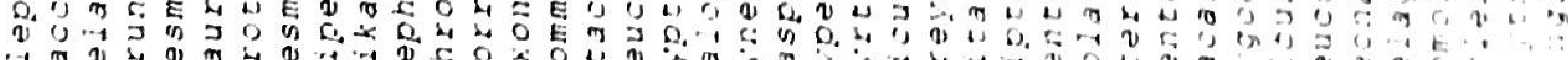

w 


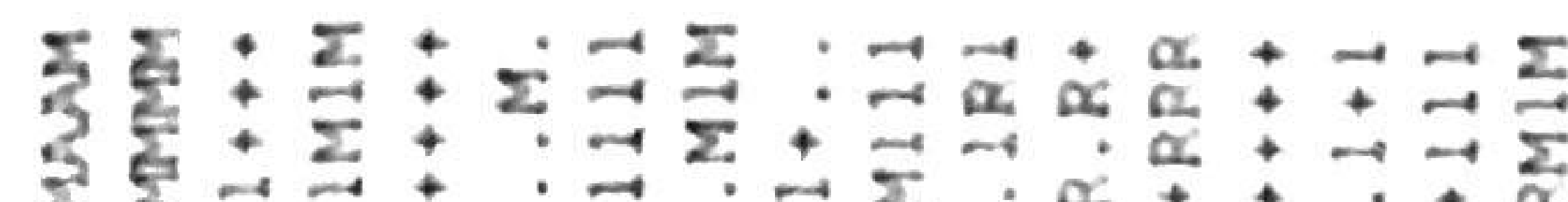

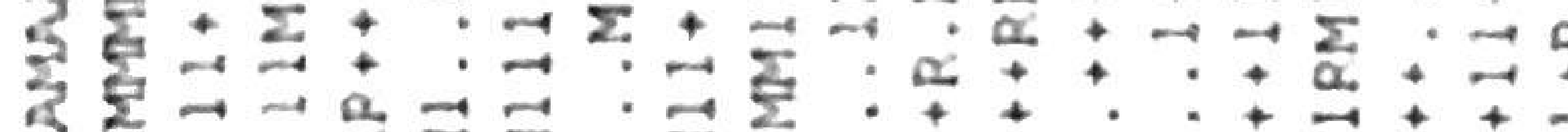

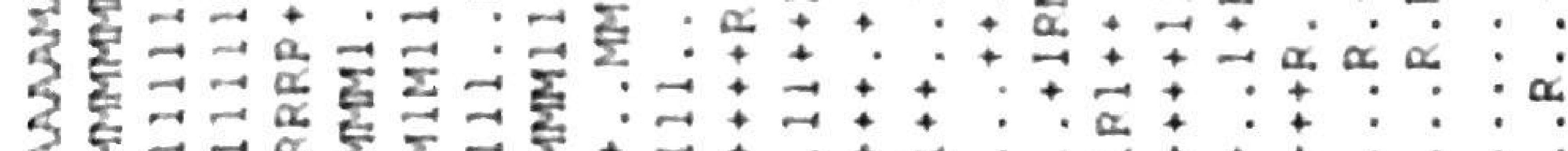

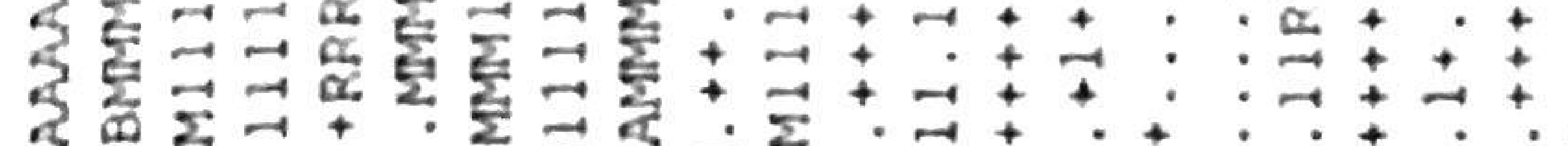

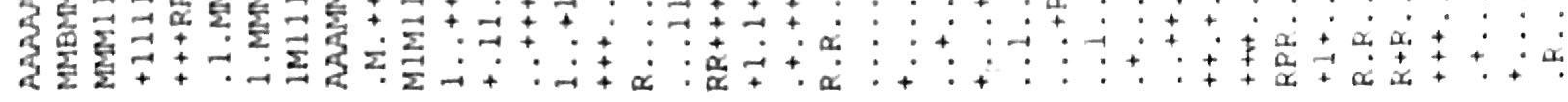

放

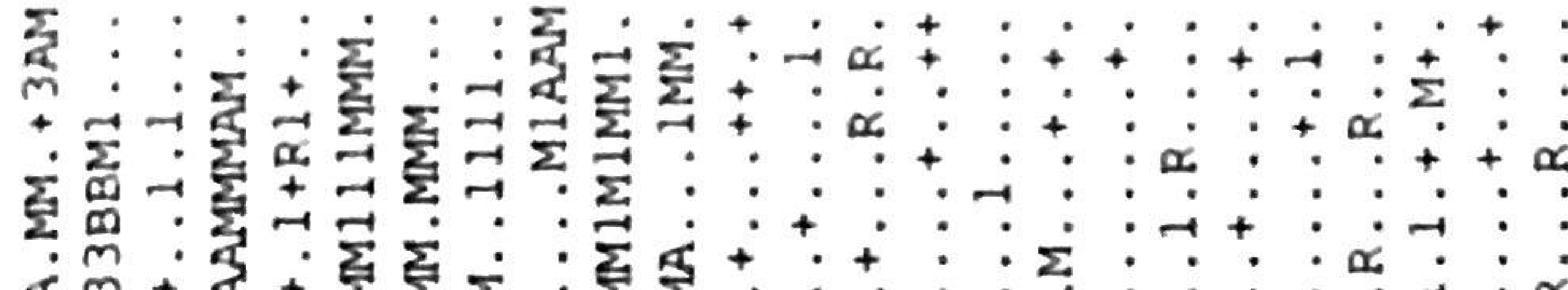

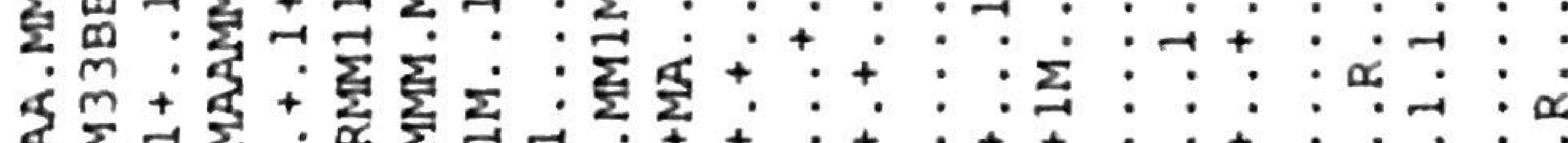

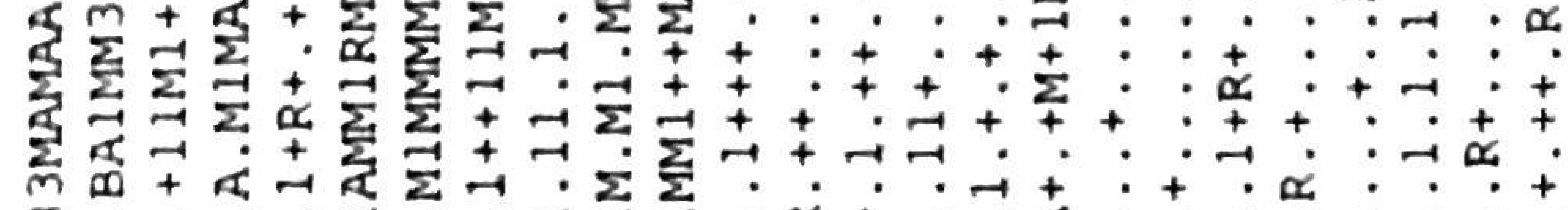

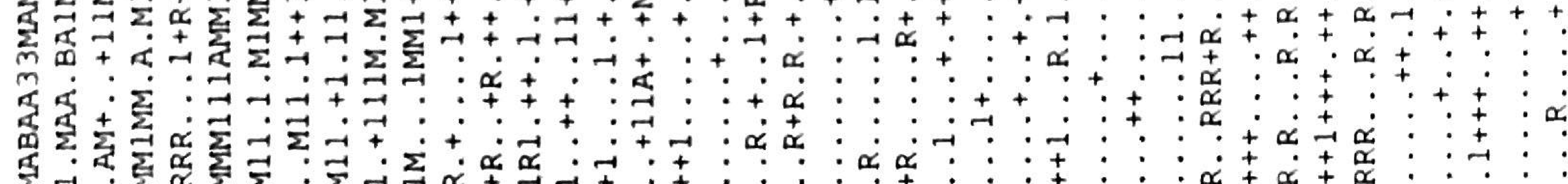

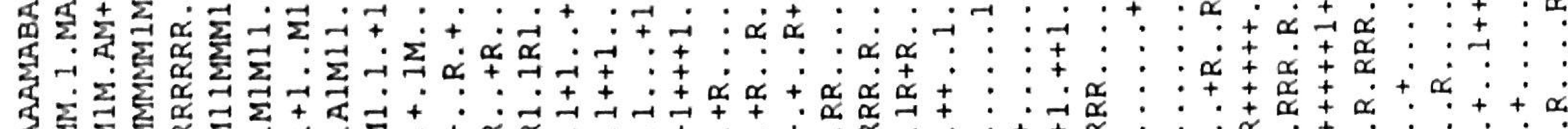

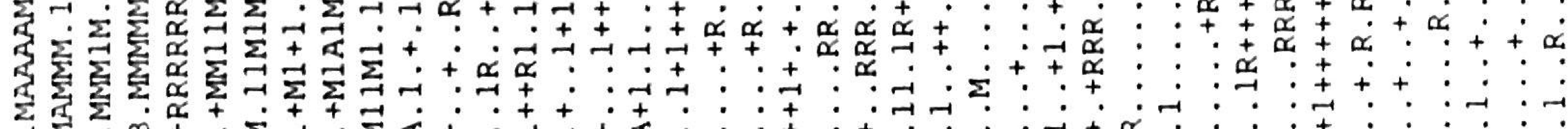

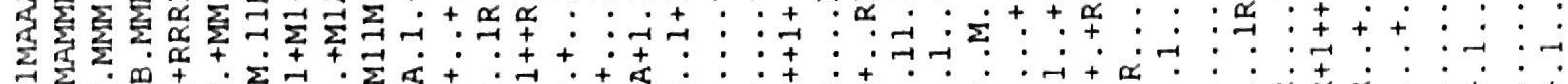

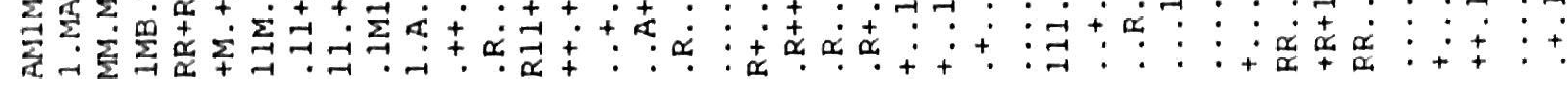

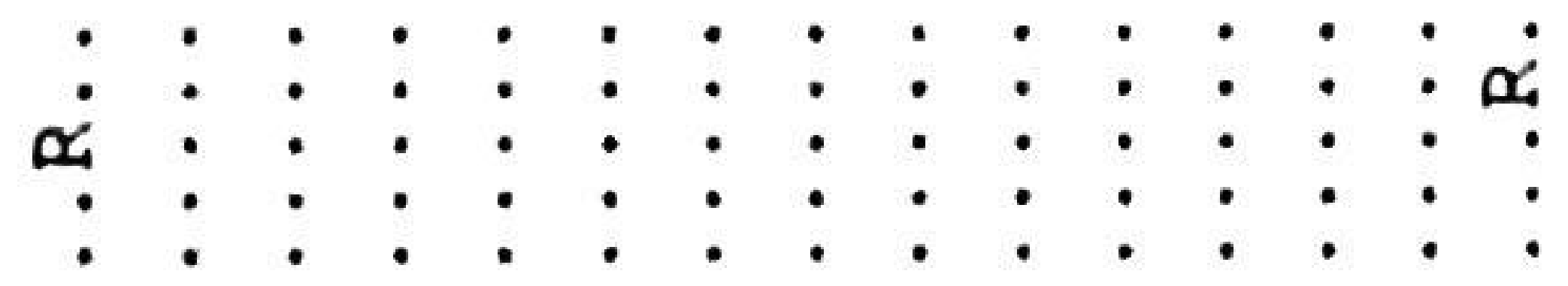

$\dot{x}$

$x$

.

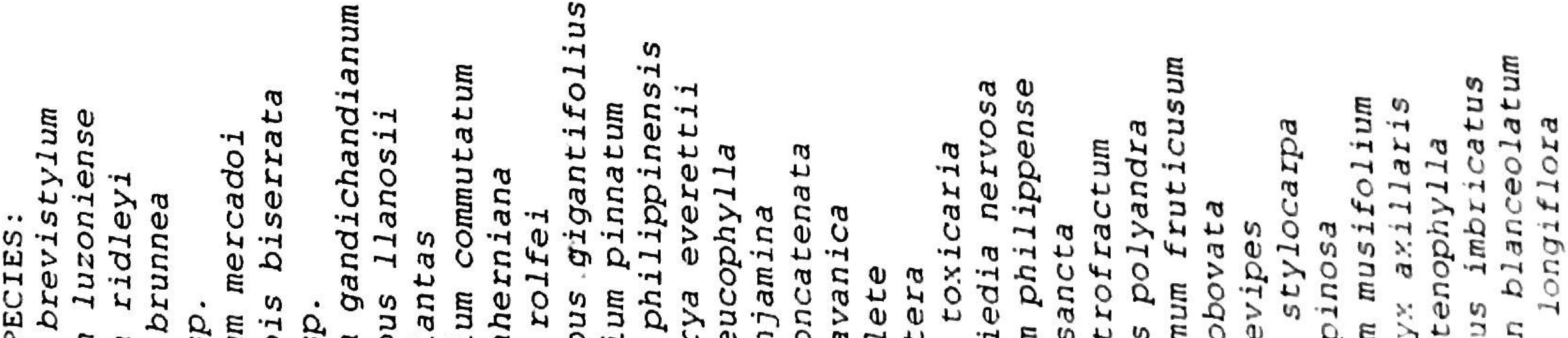

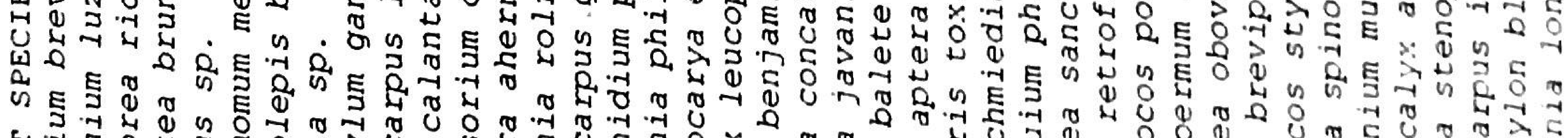

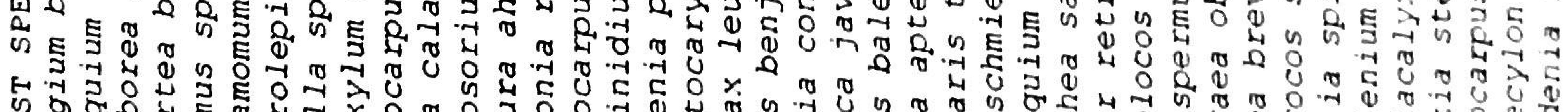

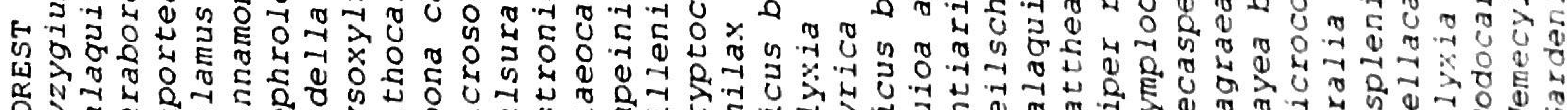
फ के 


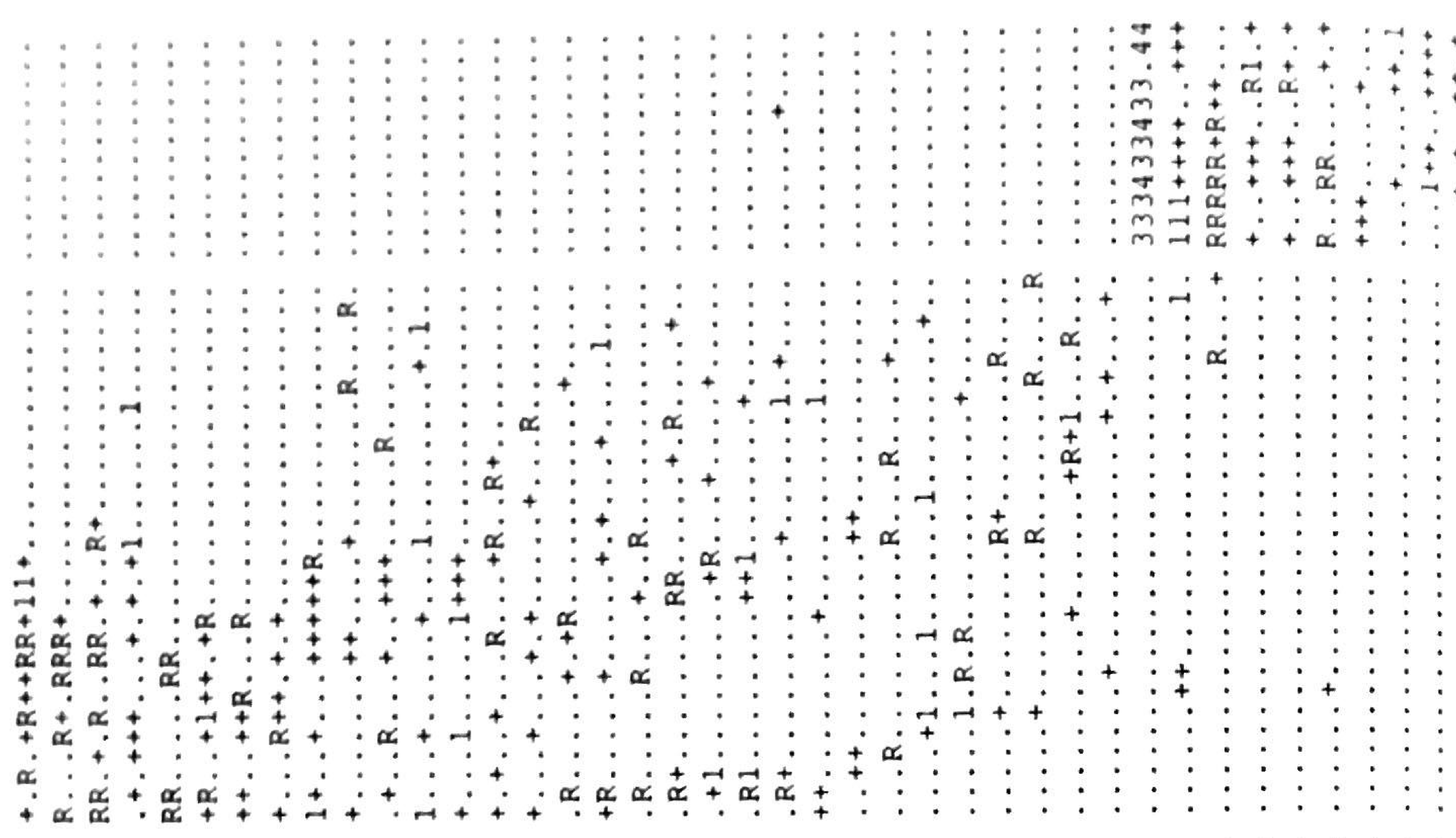




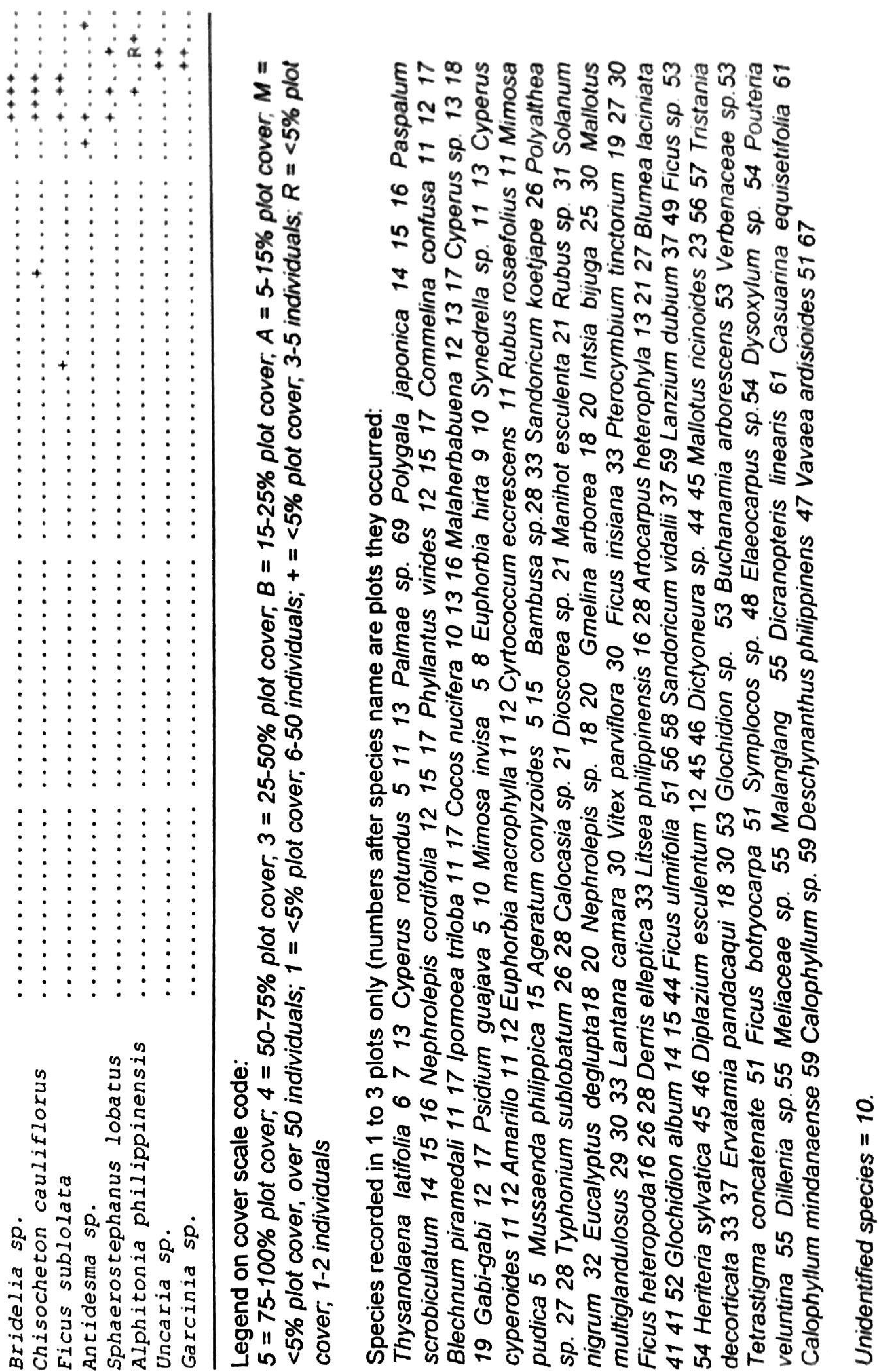

